\title{
You can't buy what you can't see: Retailer practices to increase the green premium
}

\author{
Hugo Guyader, Mikael Ottosson and Lars Witell \\ Journal Article
}

\section{Tweet}

N.B.: When citing this work, cite the original article.

Original Publication:

Hugo Guyader, Mikael Ottosson and Lars Witell, You can't buy what you can't see: Retailer practices to increase the green premium, Journal of Retailing and Consumer Services, 2016. http://dx.doi.org/10.1016/j.jretconser.2016.07.008

Copyright: Elsevier

http://www.elsevier.com/

Postprint available at: Linköping University Electronic Press

http://urn.kb.se/resolve?urn=urn:nbn:se:liu:diva-131301

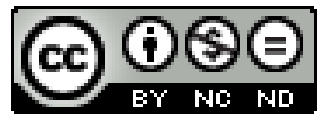




\title{
You Can't Buy What You Can't See:
}

\section{Retailer Practices To Increase The Green Premium}

\section{Guyader Hugo, ${ }^{*}$ Ottosson Mikael, Witell Lars}

Department of Management and Engineering, Linköping University, SE-581 83 Linköping, Sweden.

\begin{abstract}
Retailers are the gatekeepers between consumers and eco-friendly products. As such, they can influence green shopping behavior. The results of an eye-tracking experiment show that retailers can attract consumers' visual attention and increase the green premium through various practices such as providing relevant information, orienting consumers inside the store, and offering an eco-friendly product assortment. Managerial implications are to use green-colored price tags to signal eco-friendly products, while avoiding greenwashing practices that can distract consumers from finding the eco-friendly products they look for.
\end{abstract}

\section{Keywords}

eye-tracking, green marketing, in-store marketing, shopping behavior, visual attention

\footnotetext{
* Corresponding Author.

E-mail: hugo.guyader@liu.se

Tel.: +4613284635
} 


\section{Introduction}

Today, a growing share of consumers wish to reward businesses that are sustainable (Goldstein et al., 2008; Griskevicius et al., 2010; Tsarenko et al., 2013). These consumers are conscious of the consequences of their consumption, and if they can, they will buy eco-friendly or fair-trade groceries. That is, consumers signal and demonstrate green attitudes through their shopping behavior: They are willing to pay more for eco-friendly products (Kotler, 2011; Laroche et al., 2001; Nielsen, 2011). These eco-friendly products may be organic or manufactured from fewer natural resources and with social and ethical respect towards the labor force, requiring less energy during usage, and may be recycled. As a result, eco-friendly products are often more expensive for consumers. But from a value-based pricing perspective, such products also can be premium-priced "[...] because they have added value by being green, that is, it is not simply the added costs" (Simms, 1992, p. 39).

The "green premium," the price difference between classic and eco-friendly products, represents potential revenue for retailers (Luehr, 1992), and 77 percent of consumers state they are willing to pay such a premium (European Commission, 2013). However, eco-friendly products account for less than 4 percent of market share worldwide, especially in food retailing (Chkanikova et al., 2013). Indeed, consumers perceive eco-friendly products as ineffective (Luchs et al., 2010), judge the environmental attributes as not central to the product function (Gershoff and Frels, 2015), or simply place a stronger emphasis on the product price than on sustainability (Meise et al., 2013). Some consumers also do not trust these environmental attributes to be true (Gleim et al., 2013). 
Retailers play a key role in sustainability initiatives because of their proximity to the consumers, who make 82 percent of their purchase decisions inside the store (POPAI, 2014). Retailers act as gatekeepers who have power to introduce sustainability into the value chain (Chkanikova et al., 2013). Since Walmart introduced its sustainability index throughout its supply chain in 2008 , other retailers have adopted some of its best practices. For instance, retailers can add brands that are eco-friendly to the product assortment. By increasing the market share of ecofriendly products, retailers can achieve significant economies of scale and leverage incremental profits (RILA, 2012). Consumers generally trust the performance of wellknown brands, which is why such brands can be used to successfully introduce ecofriendly products (Pickett-Baker and Ozaki, 2008). Research also has shown that retailers can influence consumers' green shopping behavior by informing consumers inside the store through point-of-purchase (PoP) information displays and other components in the physical store environment (Gleim et al., 2013; Laroche et al., 2001; Lin and Huang, 2012; Litvine and Wüstenhagen, 2011; Mejri et al., 2012; Meise et al., 2014; Tsarenko et al., 2013). In this paper, we argue that retailers play a key role in influencing consumers to buy eco-friendly products, and inducing them to pay a higher green premium.

Our aim in this study was to analyze how retailers can attract consumers' visual attention and increase sales of eco-friendly products through in-store practices. The paper is based on an eye-tracking experiment in a supermarket mock-up in which 66 participants were invited to shop for coffee and fabric softener. The study's conclusions indicate that retailers can affect consumers' green shopping behavior by influencing their purchase intentions, through displaying relevant information, orienting them inside the store (such as signaling eco-friendly products with green 
price tags), and offering an eco-friendly product assortment. By increasing consumers' visual attention towards eco-friendly products, retailers could increase the green premium consumers paid. However, greenwashing practices (such as display of products with misleading packaging) distracted consumers who did not pay attention to eco-friendly products.

\section{Green consumer behavior}

"Green is mainstream" suggests that a majority of consumers have changed their shopping behavior towards eco-friendly products and reward companies that have environmental programs (Nielsen, 2011; Ottman, 2011). Green consumers consider the environmental consequences of their shopping behavior, balancing environmental benefits with other product attributes such as price, performance, brand image, and quality (Carrigan and Attalla, 2001; Follows and Jobber, 2000; Ottman, 2011; Young et al., 2010). Previous research has focused mainly on sociodemographic segmentation (for example, educated, middle-class, married female consumers with children at home) and psychographics (such as environmental consciousness, perceived consumer effectiveness, altruism and collectivism) to identify the characteristics of a green consumer (Diamantopoulos et al., 2003; Laroche et al., 2001; Roberts, 1995). However, we know that consumers' green shopping behavior is not as static as such segmentation models may suggest, because many consumers are green when it suits their own agendas. Moreover, each individual consumer has a different "shade of green" and perceives a product's environmental benefits differently. This suggests that green shopping behavior should be studied in situ (Hines et al., 1987; Follows and Jobber, 2000). In this paper, we discuss what may influence consumers' green shopping behavior in a 
retail store.

\section{Hypotheses Development}

The basic assumption of this research is that visual attention towards ecofriendly products influences the consumer choice process; for example, the longer consumers look at eco-friendly products, the more likely they are to pay a green premium. As a consequence, retailers can influence consumers' visual attention towards eco-friendly products and encourage their green shopping behavior in several ways, such as orienting them towards eco-friendly products, informing them, and avoiding greenwashing practices.

\subsection{Visual Attention}

Eye-tracking research shows that consumers have a higher probability of choosing a product or brand that they look at for a longer period of time (Lohse, 1994; Janiszewski, 1998). The cognitive effort required in the evaluation and verification stages of the choice process involve the consumer's visual attention. When searching for a particular product or brand, consumers perform a visual search: "[...] the process of visually scanning a scene and forming a conceptual 'image' or notion of the scene as assembled by the brain” (Duchowski, 2007, p.222). Therefore, we proposed that visual attention would influence green shopping behavior, and as a consequence, consumers would pay a higher green premium.

$\mathbf{H}_{\mathbf{1}}$. The longer consumers look at eco-friendly products, the higher the green premium paid.

\subsection{Priming Purchase Intentions}


Consumers do not necessarily behave according to their environmental attitudes when shopping for products. This attitude-behavior gap is well documented; that is, consumers may have a high concern for the environment, but display a de facto low level of green shopping behavior (Carrigan and Attalla, 2001; Follows and Jobber, 2000; Pickett-Baker and Ozaki, 2008; Vermeir and Verbeke, 2006; Young et al., 2010). Green consumers will act upon their environmental attitudes only when there is a "salience" context: social norms or sufficient situational factors (Goldstein et al., 2008; Griskevicius et al., 2010). Therefore, environmental attitudes can be dismissed in certain circumstances in favor of other personal priorities. However, framing a purchase decision influences people's behavior (e.g. Kahneman and Tversky, 1984). We argue, therefore, that retailers can prime consumers to look longer at eco-friendly products by emphasizing social norms (for example, "your friends are green consumers").

$\mathbf{H}_{2}$. Priming consumers to buy eco-friendly products will increase their visual search for these products.

\subsection{Eco-Servicescape}

Research has shown that the servicescape influences consumer behavior (Bitner, 1992; Brengman, 2002; Kauppinen-Räisänen et al., 2014). Baker et al. (2002) offered an integrative synthesis of servicescape studies in retailing and proposed that store environment cues can influence the perceived quality and value of merchandise and store patronage. As such, store design can be used to convey an environmental image to shoppers. Using photo elicitation interviews, KauppinenRäisänen et al. (2014) demonstrated the benefits of a conscious servicescape. However, they did not really show whether consumers did look at environmental 
cues or how these cues might influence their behavior. Moreover, it has been shown that the presentation style of product characteristics (Lin and Huang, 2012) and the store's signage (Otterbring et al., 2014) can influence consumers' visual attention. Therefore, the retailer's "eco-servicescape" can influence consumers to search for eco-friendly products.

$\mathbf{H}_{3}$. Visual attention towards the "eco-servicescape" impacts visual attention towards eco-friendly products.

\subsection{Point-of-Purchase $(P o P)$ Information}

Previous studies have shown that a lack of knowledge or understanding hinders consumers from making green purchase decisions (Gleim et al., 2013; Grunert et al., 2014; Hines et al., 1987; Lin and Huang, 2012; Vermeir and Verbeke, 2006; Young et al., 2010). In the absence of green information, consumers evaluate products based on price (Meise et al., 2014; Zeithaml, 1988). In fact, the perceived higher price for an eco-friendly product is commonly mentioned as a barrier to green consumption (Carrigan and Attalla, 2001; Gleim et al., 2013; Litvine and Wüstenhagen, 2011; Meise et al., 2014; Young et al., 2010). Consequently, consumers need to understand why prices are high and seek relevant information to make an informed purchase decision (Carrigan and Attalla, 2001; Gleim et al., 2013; Young et al., 2010). In this way, retailers can bridge the gap between consumers' intentions and their behavior (Tsarenko et al., 2013), and transform willingness to pay into a green premium. Providing information can help consumers to "walk the

talk" from pro-environmental intentions to behavior (Gleim et al., 2013; Litvine and Wüstenhagen, 2011). The more information that is provided, the higher consumers' perceived knowledge on eco-friendly products (Gleim et al., 2013; Laroche et al., 
2001). However, according to Grunert et al. (2014), informing consumers about sustainability through labels showed mixed results; consumers were more confused than knowledgeable.

We argue that relevant in-store information can influence the consumer's choice process for eco-friendly products. Both the environmental and individual consequences of buying a specific product factor into consumers' green purchase decisions (Auger and Devinney, 2007; Follows and Jobber, 2000); therefore, informing consumers about the benefits of an eco-friendly product (health, environment, taste) should positively influence their green shopping behavior.

$\mathbf{H}_{4}$. Consumers noticing PoP information displayed about green consumption have a higher visual attention towards eco-friendly products.

\subsection{Green Price Tags}

As consumers visually search for eco-friendly products, retailers act as gatekeepers who can arrange and signal these products, as well as orient consumers towards them. Previous research has shown that the color green is associated with outdoors and nature, which creates feelings of relaxation, happiness, comfort, peace, and hope (Clarke and Costall, 2008; Kaya and Epps, 2005). Consumers recognize something green as more likely to be organic, peaceful, and springlike (Brengman, 2002). Because consumers strongly emphasize price in their visual search, using green-colored price tags to signal eco-friendly products may direct consumers' visual attention towards eco-friendly products.

$\mathbf{H}_{5}$. Consumers who notice green price tags in their visual search pay more visual attention towards eco-friendly products. 


\subsection{Greenwashing}

Consumers often feel skeptical about the green claims that organizations make (Carrigan and Attalla, 2001; Pickett-Baker and Ozaki, 2008; Gleim et al., 2013), particularly retailers (Kauppinen-Räisänen et al., 2014; Mejri et al., 2012). "Greenwashing," or making a product look sustainable, and consumer "green fatigue" are symptoms of a lack of credibility in green marketing (Ottman, 2011). Indeed, greenwashing is a common practice: 95.5 percent of 5,296 household products found in North America were associated with a greenwashing sin, such as false labels, no proof of the claim, or vagueness (TerraChoice, 2010). Moreover, consumers use the extrinsic cue of product packaging to infer intrinsic product attributes (Underwood and Klein, 2002); that is, if the packaging color is green, consumers tend to infer that the product has nature-related attributes, even though it may not be eco-friendly. Green also can be used to evoke a brand personality (Labrecque and Milne, 2012) of strength, outdoors, and sincerity, which may increase potential greenwashing. As a result, consumers tend to distrust eco-friendly products in general, and feel less inclined to purchase them. We argued that "lighter shades" of green consumers would be more likely to fall for fake eco-friendly products, compared with "deep green" consumers who have a higher "eco-literacy" and are more knowledgeable about sustainable consumption (Laroche et al., 2001). In our experiment, we tested this argument by comparing how primed consumers and regular consumers were influenced by greenwashing. Therefore, we proposed:

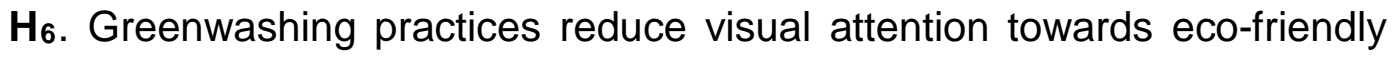
products for regular consumers to a greater extent than primed consumers. 


\section{Methodology}

\subsection{Description of Experiment}

We conducted the experiment in a retail mock-up store in Sweden, which the OECD (2008) has recognized as a "deep green" country. In 2014, the market share of green food in Sweden was 5.6 percent (Ekoweb, 2015), and in general Swedes agree that eco-friendly products are easily available (European Commission, 2013).

\subsection{Experimental Design}

We asked 66 participants to wear eye-tracking glasses during a shopping experiment in the retail mock-up store. The eye-tracking methodology was used to analyze visual attention reflected in the participants' gaze or "scanpath," composed of two salient eye movements tracked over time: (1) saccades, or rapid jumps of the eye to one location to another, and (2) fixations, or longer and still moments of the visual field (Wedel and Pieters, 2008). Optical cameras recorded the pupil center location and the infrared corneal reflection to measure the orientation of the eyes in the visual environment, also called "point of regard" measurement (Duchowski, 2007). We measured eye movements with SensoMotoric Instruments (SMI) $60 \mathrm{~Hz}$ binocular eye-tracking glasses and coded them with SMI BeGaze software. SMI eye tracking glasses had the following specifications: 1280x960p video resolution, tracking accuracy of $0.5^{\circ}$, and tracking range of $80^{\circ}$ horizontally and $60^{\circ}$ vertically. This accurate, noninvasive head-mounted optical eye tracker is the most suitable eye tracker for marketing studies (Duchowski, 2007).

All participants (mean age: 23) were students, and none had ever experienced the eye-tracking technique. Prior to the experiment, participants were briefed and a 
one-point calibration procedure was performed. Participants were instructed to buy coffee and fabric softener for someone else; tomato sauce and kidney beans were used as product fillers. The price tags and product arrangement were the same as those in ICA supermarkets (the leading retail group in Sweden). The servicescape consisted of various items evoking the countryside or agriculture, such as plants, World Wildlife Fund posters, wood, a green carpet, wooden baskets and other decorations [EcoScape].

The coffee shelves contained two coffee brands, Gevalia and Lofbergs (see Figure 1). The Gevalia shelf (to the left) had two alternatives, classic and organic coffee, and the Lofbergs shelf (to the right) had three, classic, organic, and fairtrade [GreenCoffee]. In addition, three small PoP information displays [PoP] described each of the Lofbergs products. Green price tags (vs. classic price tags) were used for each green alternative [GreenTags]. The fabric softener shelf contained four Softlan brand product alternatives (see Figure 2). Each of the three versions of the classic fabric softeners had a different packaging color: green, 
Figure 1. Coffee Shelves.

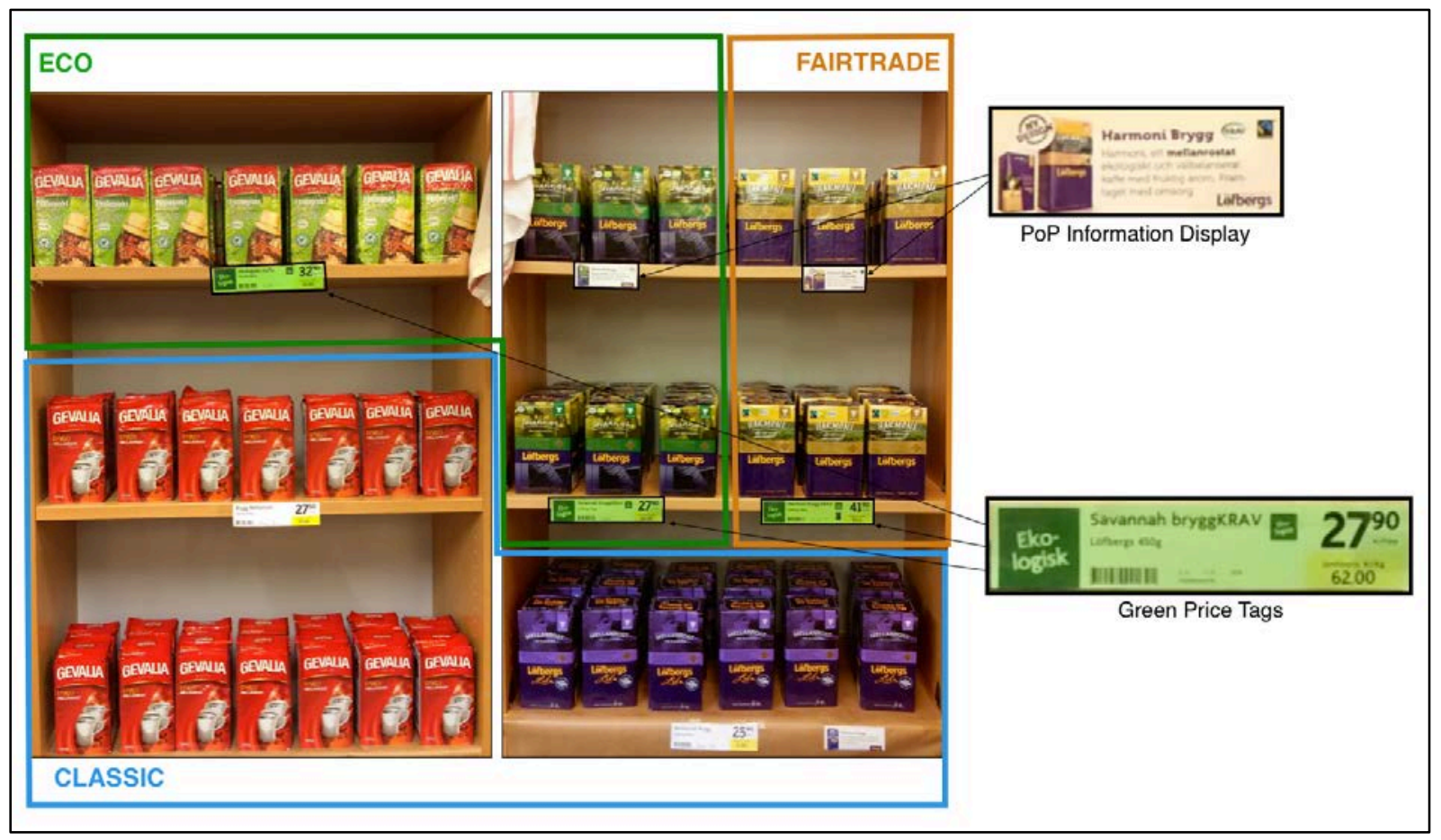

Figure 2. Fabric Softener Shelf.

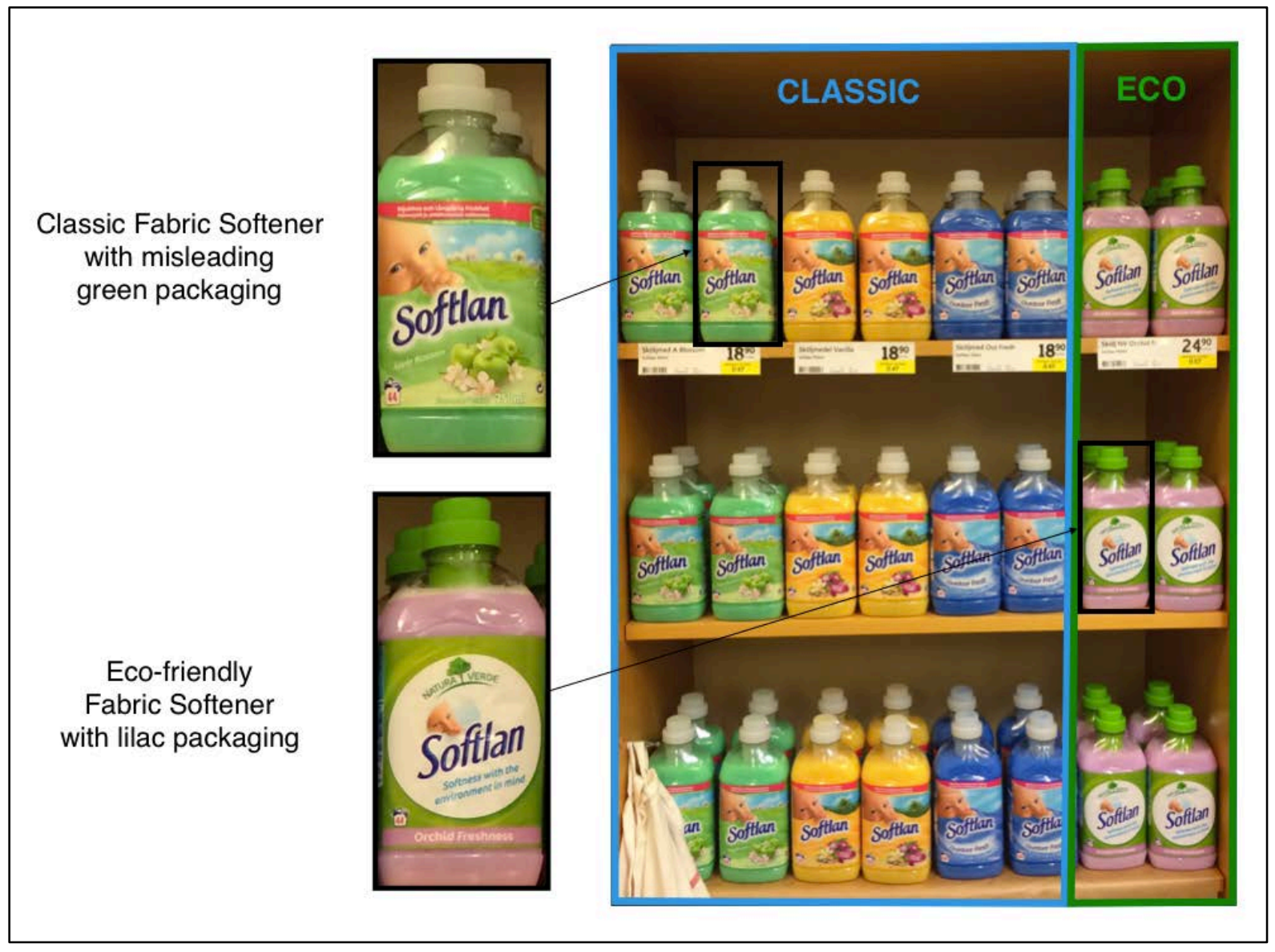


yellow, or blue. Note that the green-colored packaging could be misleading for consumers who perceived it as an eco-friendly product [GreenWashing]. The fourth alternative was the eco-friendly choice, which had a lilac-colored packaging [GreenSoft]. No green price tags were used to signal the eco-friendly fabric softener.

We used two different experimental conditions: a control group and a primed group [group], with the only difference that the primed group was told, "The person you shop for is sustainable-oriented and prefers to eat organic food." We did not alter the wording of this supplementary detail among primed participants, who were randomly distributed between each group. Eventually, the participants were asked to memorize a "consumer number," which they would have to recite to the cashier. This manipulation kept the participants cognitively busy so that they would behave as they usually do.

\subsection{Measures and Analysis}

Process, outcome, and control measures were used in the experiments. The process measures were computed from the eye-tracking data and based on dwell times (reported in milliseconds), which was the sum of fixations and saccades on objects of interests (for example, each product and each price tag). The visual attention variables were aggregated data per separate areas of interest, for example, all eco-friendly products [GreenProduct]. We deleted five outliers pairwise because they showed a small number of fixations and saccades (head movements upset the eye tracker calibration and reduced tracking accuracy). The distribution of eye tracking data often violates statistical assumptions of normality (Duchowski, 2007); therefore, we transformed all variables using the logarithm function. For details about the process measures used, see Table 1. 


\begin{tabular}{|c|c|c|c|}
\hline Name & Measure & Definition & $\begin{array}{l}\text { Mean }^{1} \\
\text { (S.D.) }\end{array}$ \\
\hline GreenProduct & $\begin{array}{l}\text { Eco-friendly } \\
\text { Products }\end{array}$ & $\begin{array}{l}\text { Sum of dwell times on all eco-friendly, } \\
\text { organic, and fair-trade products. }\end{array}$ & $\begin{array}{l}4.08 \\
(0.42)\end{array}$ \\
\hline GreenCoffee & $\begin{array}{l}\text { Eco-friendly } \\
\text { Coffee }\end{array}$ & $\begin{array}{l}\text { Sum of dwell times on organic and fair- } \\
\text { trade coffee products. }\end{array}$ & $\begin{array}{l}3.51 \\
(0.78)\end{array}$ \\
\hline GreenSoft & $\begin{array}{l}\text { Eco-friendly } \\
\text { Softeners }\end{array}$ & $\begin{array}{l}\text { Sum of dwell times on eco-friendly fabric } \\
\text { softeners (lilac color). }\end{array}$ & $\begin{array}{l}2.93 \\
(0.97)\end{array}$ \\
\hline GreenWashing & $\begin{array}{l}\text { Greenwash- } \\
\text { ing }\end{array}$ & $\begin{array}{l}\text { Sum of dwell times on classic fabric } \\
\text { softeners with misleading packaging } \\
\text { (green color). }\end{array}$ & $\begin{array}{l}2.88 \\
(0.78)\end{array}$ \\
\hline EcoScape & $\begin{array}{l}\text { Eco service- } \\
\text { scape }\end{array}$ & $\begin{array}{l}\text { Sum of dwell times on elements of the eco- } \\
\text { servicescape. Transformed into a } \\
\text { dichotomous variable (cut-off value: } 550 \\
\text { ms) to distinguish between participants } \\
\text { who noticed the eco-servicescape ( } n=32) \\
\text { and those who did not really notice it } \\
(n=29) \text {. }\end{array}$ & $\begin{array}{l}2.60 \\
(0.70)\end{array}$ \\
\hline PoP & $\begin{array}{l}\text { PoP } \\
\text { Information } \\
\text { Display }\end{array}$ & $\begin{array}{l}\text { Sum of dwell times on information displays } \\
\text { about eco-friendly coffee. Transformed into } \\
\text { a dichotomous variable between } \\
\text { participants who looked at the PoP info } \\
\text { displayed }(n=32) \text { and those who did not } \\
(n=29) \text {. }\end{array}$ & $\begin{array}{l}1.27 \\
(1.32)\end{array}$ \\
\hline GreenTags & $\begin{array}{l}\text { Green Price } \\
\text { Tags }\end{array}$ & $\begin{array}{l}\text { Sum of dwell times on price tags for eco- } \\
\text { friendly coffee products. Transformed into } \\
\text { a dichotomous variable (cut-off value: } 200 \\
\text { ms) to distinguish between participants } \\
\text { who noticed green price tags }(n=46) \text { and } \\
\text { those who did not really looked at them } \\
(n=15) \text {. }\end{array}$ & $\begin{array}{l}2.50 \\
(1.15)\end{array}$ \\
\hline
\end{tabular}

${ }^{1}$ All variables were transformed using the logarithm function.

The outcome measure was an operationalization of the green premium [GreenPremium] with an average of 53.2 percent $(S D=38.78)$, based on the spending that consumers would do on eco-friendly products. In particular, we calculated the green premium by adding 4 ordinal variables based on each participant's product choices and then logarithmically transformed it for normalization. For instance, a participant who selected the Gevalia organic coffee 
(costing 20 percent more than the regular Gevalia coffee) and the classic fabric softener had a green premium of 20 percent.

Finally, to add control measures, we used a post-experiment survey to collect socio-demographics (gender, age, household composition, and familiarity with ICA retailing) and to record participants' self-reported "greenness," using Roberts (1995) SRCB scale (24 items, Cronbach $\alpha=.886$ ). These numbers were transformed into a dichotomous variable [greenness] with a median split $(=94.5)$ to create two groups: Deep Greens $(n=33)$ and Light Greens $(n=33)$.

In the next section, we present the results from the eye tracking experiment. We discuss how we tested $\mathrm{H}_{1}$ with a regression and $\mathrm{H}_{2}$ through $\mathrm{H}_{6}$ with ANOVAs.

\section{Empirical results}

We performed a linear regression analysis to assess the relationship between visual attention to eco-friendly products [GreenProduct] and the green premium paid [GreenPremium], controlling for gender, age, household composition, and usual shopping place. The independent variables explained 43.1 percent of the variance in [GreenPremium] $(\square(5,55)=10.09, \square=.000)$, and [GreenProduct] was the only variable with a significant relationship in the model. Participants who looked at eco-friendly products paid a higher green premium; therefore, hypothesis $\mathrm{H}_{1}$ was supported.

Before testing $\mathrm{H}_{2}$, we compared the membership of the experimental groups [group] and the greenness groups [greenness] to check our manipulation process. As indicated by a chi-square test for independence, $\square^{2}(1, n=66)=3.911, \square=.048$ (twotailed), the primed group had a significantly higher greenness than the control group. There was a statistically significant difference in [GreenProduct] between [group] as determined by an ANOVA $(\square(1,59)=16.986, \square=.000)$. The eye-tracking data showed 
that the primed group looked longer on the eco-friendly products. As a result, retailers can use priming to significantly raise consumers' visual attention towards their eco-friendly product assortment. Therefore, hypothesis $\mathrm{H}_{2}$ was supported. However, there were no statistically significant differences in [GreenProduct] depending on whether the participants looked long enough at the eco-servicescape [EcoScape], as determined by an ANOVA $(\square(1,59)=.427, \square=.516)$. Therefore, $\mathrm{H}_{3}$ was not supported.

We tested the hypotheses about PoP information displays and green price tags $\left(\mathrm{H}_{4}\right.$ and $\left.\mathrm{H}_{5}\right)$ using the coffee shelves only (see Figure 1). There was a statistically significant difference in [GreenCoffee] depending on whether participants looked at $[P o P]$ as determined by an ANOVA $(\square(1,59)=3.096, \square=.022)$. The group who noticed the PoP information display spent more time looking at eco-friendly coffee than those who did not; therefore, hypothesis $\mathrm{H}_{4}$ was supported. In addition, there was a significant difference in [GreenCoffee], depending on whether participants looked long enough at the green price tags [GreenTags], as determined by an ANOVA $(\square(1,59)=5.989, \square=.017)$. Participants who looked at green price tags were more likely to look at the eco-friendly coffee; therefore, hypothesis $\mathrm{H}_{5}$ was supported

Among the coffee products, the eco-friendly alternatives were easily identifiable, but among the fabric softeners, the eco-friendly alternative had lilaccolored packaging, and one of the classic alternatives had a misleading green packaging (see Figure 2). We conducted a repeated-measures ANOVA with a Greenhouse-Geisser correction to compare visual attention towards [GreenSoft] and [GreenWash] between [group]. There was a significant difference in both measures, Wilks' $\lambda=.914, \square(1,59)=5.565, \square=.022$ (moderate effect size). Participants who looked at the "greenwashed" alternative were more likely to miss the true eco- 
friendly fabric softener, but not if they were searching for it; therefore, hypothesis $\mathrm{H}_{6}$ was supported. "Deep green" consumers who visually search for eco-friendly products (represented by the primed group) are significantly less likely to be influenced by greenwashing practices. These consumers looked at the "greenwashed" alternative for comparatively less time than at the true eco-friendly fabric softeners. Figure 3 displays the average time spent (in milliseconds) looking at the eco-friendly and the "greenwashed" fabric softeners for the two groups.

Figure 3. Mean plot of Visual Attention on Fabric Softeners.

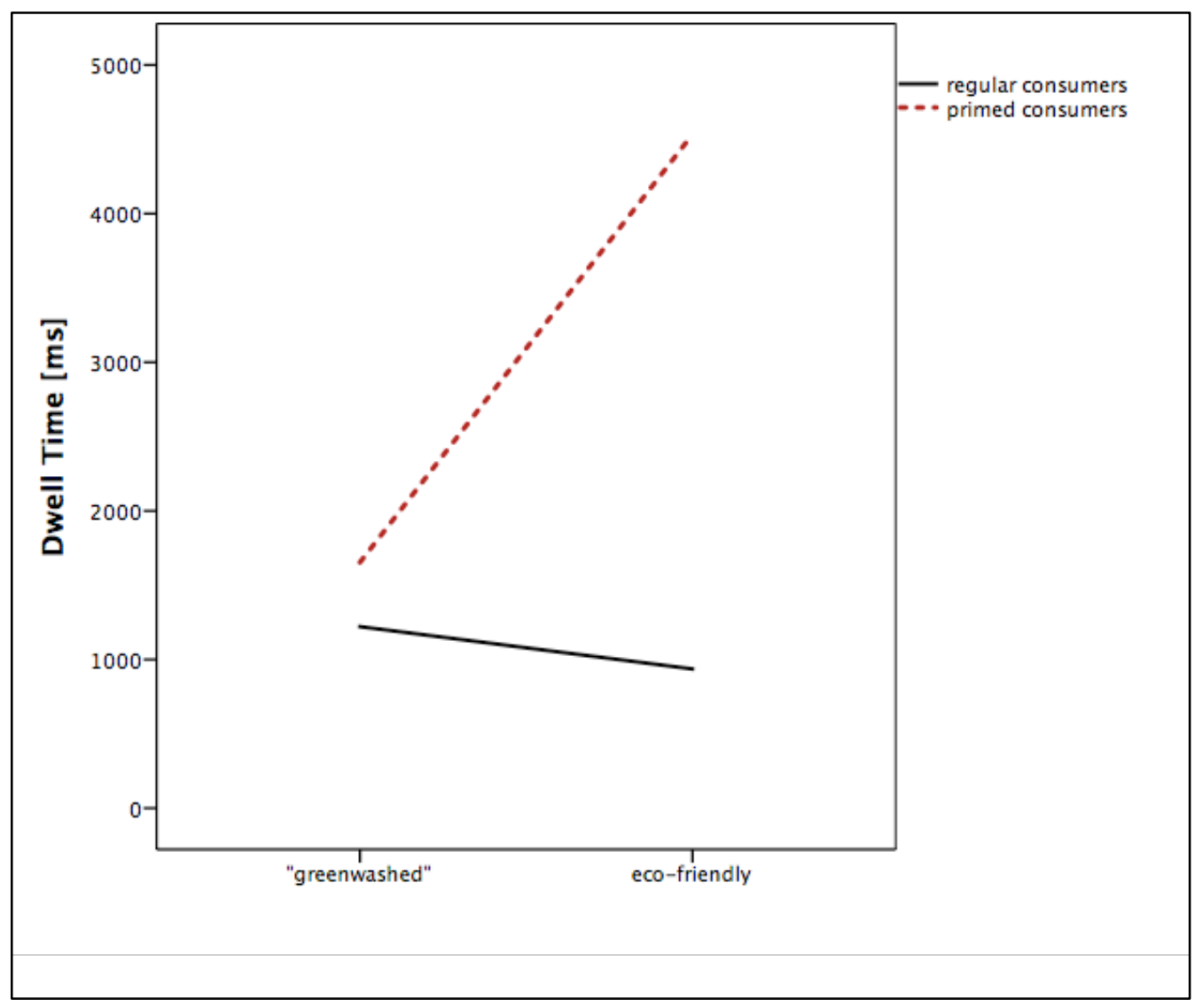

6.

\section{Discussion}

This study showed that retailers could influence consumers' green shopping behavior through in-store marketing practices. Retailers can influence consumers' intentions to make green purchases by displaying relevant information, orienting consumers inside the store, and offering an eco-friendly product assortment. 
However, greenwashing practices can distract consumers who are not looking for eco-friendly products.

First, the study showed that consumers who looked longer at the eco-friendly products paid a higher green premium. By orienting visual attention towards these products, retailers can induce consumers to notice them, process information, and consider buying them (see Wedel and Pieters, 2008). PoP information displays, successfully oriented consumers to look at eco-friendly products. In other words, consumers became more knowledgeable about the green products and compared them with other alternatives (Gleim et al., 2013; Laroche et al., 2001).

Second, the primed group was representative of "deep green" consumers who have a purchase intention and genuinely search for eco-friendly products. Influenced by social norms, consumers are more likely to act upon their environmental attitudes (Goldstein et al., 2008; Griskevicius et al., 2010). Indeed, the primed group actually spent more time searching for and looking at eco-friendly products, which resulted in a higher green premium.

Third, the study showed that the color green had a strong influence on consumer visual attention, because it tends to indicate organic and natural characteristics (Brengman, 2002; Kaya and Epps, 2005). As such, green price tags helped consumers find the eco-friendly products they sought. This finding confirmed that green is associated with eco-friendly products. However, greenwashing practices, such as using the color green to lure consumers into buying a classic product, considerably reduced visual attention towards the true eco-friendly products. Packaging implies product attributes (Underwood and Klein, 2002), and therefore, consumers who notice a green-colored packaging may be duped into believing its contents are actually eco-friendly, even when they are not. "Lighter 
green" consumers will spend less time comparing alternatives and base their purchase decision on price.

Finally, we expected that an eco-servicescape would impact the consumers' attention towards eco-friendly products, but these results were insignificant. Kauppinen-Räisänen et al. (2014) showed that retailers who seek to communicate environmental consciousness through the servicescape should display authenticity and trustworthiness. A post-experiment debrief with the participants confirmed that the tentative eco-servicescape turned out to "look fake," to be "too artificial," or showed "no effort in convincing." Eventually, participants in the control group (vs. priming) seemed less likely to "notice any décor," and it may even have distracted consumers from their choice process.

\subsection{Managerial implications}

A pro-environmental marketing approach is necessary for retailers if they want to attract the green consumer and increase the revenues from eco-friendly products (Kotler, 2011; Pickett-Baker and Ozaki, 2008; RILA, 2012). This study showed that retailers could increase visual attention towards eco-friendly products with practices inside the store. That is, participants who looked longer at the eco-friendly alternatives of coffee and fabric softener products, balancing environmental benefits against the traditional alternatives, paid a higher green premium. This finding implies that retailers can achieve greater sales and profits by increasing the retail space devoted to eco-friendly products. Moreover, retailers should display PoP information and green-colored price tags to inform and signal eco-friendly products to consumers. Retailers can also influence consumers' intentions by rewarding their green purchase decisions (for instance, loyalty programs) and by priming them to 
look harder for eco-friendly products in the store (mailed promotions emphasizing social norms).

However, retailers should avoid greenwashing practices (such as displaying products with misleading packaging). Previous studies have shown that consumers are skeptical towards retailers' sustainability agenda (Kauppinen-Räisänen et al., 2014; Mejri et al., 2013). Retailers should take responsibility for selecting a product assortment that is not misleading consumers, otherwise they will reduce visual attention towards true eco-friendly products, and in turn, the associated green premium. Since consumers generally trust well-known brands, these can be used to successfully introduce eco-friendly products. Eventually, lowering the price gap between eco-friendly and traditional products (e.g. through retail brands that absorb some of the gap) can influence consumers to buy greener.

\subsection{Limitations and further research}

Eye-tracking studies are based on the assumption that the point of regard and the overt movements of the eyes reflect one's attention (Duchowski, 2007). However, this assumption has a major bias: Attention is also influenced by a covert component. For instance, in this study, we did not control for (top-down) memory effects on choice, such as brand familiarity. Another limitation from the experimental design is that participants did not actually have to pay. Although some of them mentioned in the post-experiment debrief that they acted "as usual," they may have been less concerned about price than they normally would be. Further research should be conducted in actual retail settings, in situ (Hines et al., 1987; Follows and Jobber, 2000). Eventually, the experiment's external validity may be limited because we considered students to be similar to household consumers (cf. Peterson, 2001). 
The use of the eye-tracking technique in studying consumers' green shopping behavior revealed the impact of visual attention towards eco-friendly products in the choice process. Further research should investigate what information consumers process in the packaging elements (for example, labels, ingredients, and textual versus pictorial information) when they fixate a product for longer time. Neuromarketing studies investigating these packaging details by monitoring brain activity with electroencephalography coupled with stationary eye-tracking methodology would shed more light on the influence of visual attention in the consumer choice process.

In this experiment, we did not investigate the long-term effects of information on consumers' environmental knowledge and subsequent recall. Further research should study the effect of mere exposure to relevant green information on consumers and how it impacts their behavior (both in-store and post-purchase). For instance, a longitudinal study using retailing data could investigate the impact of "eco-literacy" (Laroche et al., 2001) on green shopping behavior over time.

\section{Acknowledgement}

The authors are grateful to Linnea Björk Timm for assistance with the eyetracking set up.

\section{References}

Auger, P., Devinney, T.M., 2007. Does what consumers say matter? The misalignment of preferences with unconstrained ethical intentions. J. Bus. Ethics 76(4), 361-383.

Baker, J., Parasuraman, A., Grewal, D., Voss, G.B., 2002. The influence of multiple store environment cues on perceived merchandise value and patronage intentions. J. Mark. 66(4), 120-141.

Bitner, M.J., 1992. Servicescapes: The impact of physical surroundings on customers and employees. J. Mark. 56(4), 57-71.

Brengman, M., 2002. The impact of colour in the store environment. An environmental psychology approach [doctoral dissertation]. Ghent University, Belgium. 
Carrigan, M., Attalla, A., 2001. The myth of the ethical consumer: Do ethics matter in purchase behaviour? J. Consum. Mark. 18(7), 560-578.

Chkanikova, O., Klintman, M., Kogg, B., Lehner, M., Mont, O., Nebelius, N., Plepys, A., 2013. Sustainability landscape of Swedish food retailers in the European context [report]. International Institute for Industrial Environmental Economics, Lund University, Sweden. Available at: http://lup.lub.lu.se/record/4330902/file/4330907.pdf

Clarke, T., Costall, A., 2008. The emotional connotations of color: A qualitative investigation. Color Res. Appl. 33(5), 406-410.

Diamantopoulos, A., Bohlen, G.M., Schlegelmilch, B.B., Sinkovics, R.R., 2003. Can sociodemographics still play a role in profiling green consumers? A review of the evidence and an empirical investigation. J. Bus. Res. 56(6), 465-480.

Duchowski, A.T., 2007. Eye-tracking methodology: Theory and practice. Springer-Verlag, London.

Ekoweb, 2015. Ekologisk livsmedelsmarknad [report]. Ekoweb Sverige, Lidköping, Sweden. Available at: http://www.ekoweb.nu/attachments/67/27.pdf

European Commission, 2013. Attitudes of Europeans towards building the single market for green products[report]. Flash Eurobarometer 367, Directorate-General for Communication. Available at: http://ec.europa.eu/public_opinion/flash/fl_367_en.pdf.

Follows, S., Jobber, D., 2000. Environmentally responsible purchase behavior: A test of a consumer model. European J. Mark. 34(5/6), 723-746.

Gershoff, A.D., Frels, J.K., 2015. What makes it green? The role of centrality of green attributes in evaluations of the greenness of products. J. Mark. 79(1), 97-110.

Gleim, M.R. Smith, J.S., Andrews, D., Cronin, J.J., 2013. Against the green: A multi-method examination of the barriers to green consumption. J. Retail. 89(1), 44-61.

Goldstein, N.J., Cialdini, R.B., Griskevicius, V. 2008. A room with a viewpoint: Using social norms to motivate environmental conservation in hotels, J. Consum. Res. 35(3), 472-482.

Griskevicius, V., Tybur, J.M., Van den Bergh, B., 2010. Going green to be seen: Status, reputation, and conspicuous conservation. J. Pers. Soc. Psychol. 98(3), 392-404.

Grunert, K.G., Hieke, S., Wills, J., 2014. Sustainability labels on food products: Consumer motivation, understanding and use. Food Policy 44(2), 177-189.

Hines, J.M., Hungerford, H.R., Tomera, A.N., 1987. Analysis and synthesis of research on responsible environmental behavior: A meta-analysis. J. Environ. Educ. 18(2), 1-8.

Janiszewski, C., 1998. The influence of display characteristics on visual exploratory search behavior. J. Consum. Res. 25(3), 290-301.

Kahneman, D., Tversky, A., 1984. Choices, values, and frames. Am. Psychol. 3(4), 341-50.

Kauppinen-Räisänen, H., Rindell, A., Åberg, C., 2014. Conveying conscientiousness: Exploring environmental images across servicescapes. J. Retail. Consum. Serv. 21(4), 520-528.

Kaya, N., Epps, H.H., 2005. Color-emotion associations: Past experience and personal preference. In: AIC 2004, Color and Paints, Interim Meeting of the International Color Association, Porto Alegre, Brazil, Proceedings, Caivano J.L., 31-34.

Kotler, P., 2011. Reinventing marketing to manage the environmental imperative. J. Mark. 75(4), 132135.

Labrecque, L.I., Milne, G.R., 2012. Exciting red and competent blue: The importance of color in marketing. J. Acad. Mark. Sci. 40(5), 711-727.

Laroche, M., Bergeron, J., Barbaro-Forleo, G., 2001. Targeting consumers who are willing to pay more for environmentally friendly products. J. Consum. Mark. 18(6), 503-520.

Lin, P.C., Huang, Y.H., 2012. The influence factors on choice behavior regarding green products based on the theory of consumption values. J. Clean. Prod. 22(1), 11-18.

Litvine, D., Wüstenhagen, R., 2011. Helping "light green" consumers walk the talk: Results of a behavioural intervention survey in the Swiss electricity market. Ecol. Econ. 70(3), 462-474.

Lohse, G.L., 1994. Consumer eye movement patterns on Yellow Pages advertising. J. Advert. 26(1), 61-73.

Luchs, M.G., Naylor, R.W., Irwin, J.R., Raghanathan, R., 2010. The sustainability liability: Potential negative effects of ethicality on product preference. J. Mark. 74(5), 18-31. 
Luehr, P.H., 1992. Guiding the green revolution: The role of the Federal Trade Commission in regulating environmental advertising. UCLA J. Environ. Law Policy 10(2), 311-336.

Meise, J.N., Rudolph, T., Kenning, P., Phillips, D.M., 2014. Feed them facts: Value perceptions and consumer use of sustainability-related product information. J. Retail. Consum. Serv. 21(4), 510519.

Mejri, C.A., Bhatli, D., Benhallam, M., 2012. Why art thou resisting? Consumer resistance to the 'citizen argument' of retailers. Int. J. Mark. Res. 54(5), 707-722.

Nielsen, 2011. The "green" gap between environmental concerns and the cash register [report]. Available at: http://www.nielsen.com/us/en/insights/news/2011/the-green-gap-betweenenvironmental-concerns-and-the-cash-register.html

OECD, 2008. Promoting sustainable consumption. Good practices in OECD countries [report]. Organization for Economic Co-operation and Development, Paris, France. Available at: www.oecd.org/greengrowth/40317373.pdf

Otterbring, T., Wästlund, E., Gustafsson, A., Shams, P., 2014. Vision (im)possible? The effects of instore signage on customers' visual attention. J. Retail. Consum. Serv. 21(5), 676-684.

Ottman, J.A., 2011. The new rules of green marketing: Strategies, tools, and inspiration for sustainable branding. Berrett-Koehler Publishers, San Francisco.

Peterson, R.A., 2001. On the use of college students in social science research: Insights from a second-order meta-analysis. J. Consum. Res. 28(3), 450-461.

Pickett-Baker, J., Ozaki, R., 2008. Pro-environmental products: marketing influence on consumer purchase decision. J. Consum. Mark. 25(5), 281-293.

POPAI, 2014. Mass merchant shopper engagement study [report]. Point of Purchase Advertising International, Chicago, USA. Available at: http://www.popai.com/Research\%20Library/popaimass-merchant-shopper-engagement-study.pdf

RILA, 2012. 2012 retail sustainability report: Successes, challenges, and a vision for the future [report]. Retail Industry Leaders Association. Available at: http://www.rila.org/sustainability/sustreport2013/sustainability-report-landingpage/Documents/2012RetailSustainabilityReport.pdf

Roberts, J.A., 1995. Profiling levels of socially responsible consumer behavior: A cluster analytic approach and its implications for marketing. J. Mark. Theory Pract. 3(4), 97-117.

Simms, C., 1992. Green issues and strategic management in the grocery retail sector. Int. J. Retail Distrib. Manag. 20(1), 32-42.

TerraChoice, 2010. The sins of greenwashing, home and family edition: A report on environmental claims made in the North American consumer market [report]. Underwriters Laboratories. Available at: http://sinsofgreenwashing.com/index35c6.pdf

Tsarenko, Y., Ferraro, C., Sands, S., McLeod, C., 2013. Environmentally conscious consumption: The role of retailers and peers as external influences. J. Retail. Consum. Serv. 20(3), 302-310.

Underwood, R.L., Klein, N.M., 2002. Packaging as brand communication: Effects of product pictures on consumer responses to the package and brand. J. Mark. Theory Pract. 10(4), 58-68.

Vermeir, I., Verbeke, W., 2006. Sustainable food consumption: Exploring the consumer "attitudebehavioral intention" gap. J. Agric. Environ. Ethics 19(2), 169-194.

Wedel, M., Pieters, R., 2008. A review of eye-tracking research in marketing. In Malhotra, N. (Ed.), Review of marketing research, Sharpe Inc, New York, pp. 123-146.

Young, W., Hwang, K., Mcdonald, S., Oates, C.J., 2010. Sustainable consumption: Green consumer behaviour when purchasing products. Sustain. Dev. 18(1), 20-31.

Zeithaml, V., 1988. Consumer perceptions of price, quality, and value: A means-end model and synthesis of evidence. J. Mark. 52(3), 2-22. 